\title{
Development of Low-salt Fish Sauce Using High Levels of Yeast
}

\author{
Maehashi Kenji* and Yamamoto Yasushi* \\ * Department of Fermentation Science, Tokyo University of Agriculture \\ 1-1-1, Sakuragaoka, Setagaya-ku, Tokyo 156-8502
}

\begin{abstract}
We formulated a method for preparing low-salt fish sauce using soy sauce yeast. In $10 \% \mathrm{NaCl}$ fish sauce mash, to which $5 \%$ ethanol was added, bacterial growth was nearly $10^{2}$ colony forming units (cfu)/g throughout the fermentation period; in fish sauce mash without ethanol, the bacterial population markedly increased beyond $10^{8} \mathrm{cfu} / \mathrm{g}$ in the first 10 days of fermentation. To prepare the low-salt fish sauce, we isolated the A-9 strain of the yeast Zygosaccharomyces rouxii from soy sauce mash $; 10^{6}$ cells/g of the strain was added to fish with $10 \%$ glucose or $22 \%$ wheat koji as the carbon source for alcohol fermentation to prepare a $10 \% \mathrm{NaCl}$ fish sauce mash. In the mash, yeast produced alcohol as they grew, which inhibited the growth of bacteria. Fermentation was complete in 60 days, and the mixture was pressed to obtain liquid. The low-salt fish sauce prepared with high levels of yeast in this study had a half concentration of $\mathrm{NaCl}$ and a more favorable fermented flavor than commercial fish sauces made in the traditional manner.
\end{abstract}

(Received May 9, 2007 ; Accepted Oct. 2, 2007)

Key words : fish sauce, low-salt, Zygosaccharomyces rouxii, koji

魚奨油, 低食塩, Zygosaccharomyces rouxii, 麹

Fish sauce is a clear amber liquid seasoning produced through the autolysis of salted fish. It has a strong umami taste owing to the presence of abundant amino acids and peptides that originate from the fish meat. However, because of its high salt content and distinctive odor, its use in Japanis still limited in some regions. Fish sauce usually contains $20 \sim 25 \% \mathrm{NaCl}$. From the perspective of health, a reduction in $\mathrm{NaCl}$ content is desirable, which can also increase the appeal of the product to a wider range of consumers. However, salt reduction during the manufacturing of fish sauce increases the risk of spoilage during the aging process. The high $\mathrm{NaCl}$ content in fish sauce mash extends the aging period; however, many odorants are formed during this period. Dougan and HowARD ${ }^{1)}$ reported that the aroma of fish sauce has three distinct components : cheesy, meaty, and ammoniacal. Several reports ${ }^{2)}$ ) have been published on volatile compounds as odorants in fish sauce. It has also been reported that some parts of the odorants are created from various amino acids by bacteria or by auto-oxidation of lipids during long-term fermentation $^{3,6)}$. In soy sauce manufacture, there are several ways to reduce the $\mathrm{NaCl}$ content without spoilage. The use of high levels of yeast for making soy sauce has been reported by Матsumoto and $\mathrm{IMAI}^{\text {7) }}$ for the purpose of making a low-salt product at a low cost without any special apparatus. In this method, $Z$. rouxii $\left(10^{6}\right.$ cells $\left./ \mathrm{g}\right)$ was added to the materials to be fermented to make a soy sauce containing $10 \% \mathrm{NaCl}$ without spoilage. We anticipated that this method would be adaptable for making low-salt fish sauces.

We describe here the use of high levels of yeast to produce low-salt fish sauce with a strong umami taste and favorable flavor in a short time period.

\section{Materials and Methods}

\section{Materials}

Anchovy (length : $13 \mathrm{~cm}$ ) were purchased from a Japanese fish market and processed within a day after they were caught. The fish had been stored in iced water between catch and processing. The salt used to prepare the fish sauce was $95 \%$ pure $\mathrm{NaCl}$ (Shin Nihon Salt Co., Japan). Ethanol (purity : 99.5\%) was purchased from Wako Co. (Osaka, Japan). Four commercially available fish sauces

* E-mail : MAEHASHI Kenji ; maehashi@nodai.ac.jp, YAmAmoto Yasushi ; yamayasu@nodai.ac.jp 
made in Vietnam, Thailand, and Japan were purchased as a traditional fish sauce from a local market in Japan.

\section{Preparation of koji}

Koji is an enzyme preparation produced from cereals or pulses that is used as a starter for traditional fermented foods such as soy sauce and miso. For soy sauce, cracked wheat and whole or defatted soybean are usually used as the starter material. We used wheat flour as the starter material for koji because of its higher content of carbohydrate and glutamic acid, which is an umami taste substance.

Wheat flour (Koji-Mugi ST; Nisshin Flour Milling Co.) was added to warm water $\left(40^{\circ} \mathrm{C}\right)$ to give $30 \sim$ $35 \%$ moisture and then seeded with spores $(0.5 \mathrm{~g} /$ kgwheat) of Aspergillus sojae (Tane-Koji ; Bioc Co., Aichi, Japan). This mixture was wrapped in cotton fabric and incubated for $15 \mathrm{~h}$ in a room airconditioned to $28^{\circ} \mathrm{C}$ and $90 \%$ relative humidity. After the mold germinated, the mixture was spread thinly on a wooden tray and incubated further. Because the mold formed a cake as it grew (via respiration), the clump of mold was broken up by hand, cooled to $30^{\circ} \mathrm{C}$, and supplied with fresh air every $6 \mathrm{~h}$ during the second incubation. After $45 \mathrm{~h}$ of incubation, koji was removed from the airconditioned room and left under an ambient atmosphere to dry and arrest its growth.

\section{3 . Small-scale preparation of low-salt fish sauce}

Anchovy were cut into pieces 3 or 4 cmlong and minced in a blender. The minced fish was mixed with salt, glucose, or koji and cultured yeast cells as shown in Table 1. The yeast was cultured in YM broth $(0.3 \%$ yeast extract, $0.3 \%$ malt extract, $1 \%$ polypeptone, and $10 \%$ glucose; $\mathrm{pH} 5.5$ ) containing $10 \% \mathrm{NaCl}$ for 3 days. The cells were then harvested by centrifugation. After the cells were suspended in a small amount of $10 \% \mathrm{NaCl}$ solution, the number of cells was counted with a hemacytometer, and the cells were added to the mixture of minced fish and salt at a concentration of $10^{6}$ cells $/ \mathrm{g}$. The mixture was placed in a glass pot, sealed tightly, and incubated at $30^{\circ} \mathrm{C}$ for 2 months. After fermentation was complete, the fish sauce mashes were pressed to obtain liquid.

\section{Counting viable cell number of bacteria and yeast in fish sauce mash}

Ten grams of each fish sauce mash was diluted to $100 \mathrm{~m} \ell$ with $10 \% \mathrm{NaCl}$ solution. Then, $1 \mathrm{~m} \ell$ of the suspension was further diluted and transferred to a dish and mixed with BPG medium ( $\mathrm{pH} \mathrm{7.0})^{8)}$, composed of $0.5 \%$ bonito extract, $0.5 \%$ polypeptone, $1 \%$ glucose, $1 \% \mathrm{MgSO}_{4}, 0.1 \% \mathrm{KCl}, 5 \% \mathrm{NaCl}$, and $1.5 \%$ agar, for the counting of bacteria. Cycloheximide (50 ppm of final concentration) was added to the BPG medium to prevent fungal contamination. For counting yeast, YM $(0.3 \%$ yeast extract, $0.3 \%$ malt extract, $1 \%$ polypeptone and $10 \%$ glucose, $1.5 \%$ agar, $\mathrm{pH} 5.5$ ) containing $10 \%$ $\mathrm{NaCl}$ was used instead of BPG medium. After incubation at $30^{\circ} \mathrm{C}$ for 4 days, the number of colonies formed was counted to calculate colony forming units (cfu) per $1 \mathrm{~g}$ of mash.

\section{Isolation and identification of bacteria from fish sauce mash}

Bacteria isolated from the fish mash were identified on the basis of their morphological and biochemical properties in accordance with Bergey's manual $^{9)}$. The external properties, including shape, gram stain type, endospore presence, and motility, were recorded by the methods of FUJII and SAKAI ${ }^{10}$. Biochemical properties, such as catalase activity, oxidase activity, and gas produced from glucose, were examined in accordance with Fujii et $a l^{8)}$. and Cowan and Steel's Manual ${ }^{11)}$. Phylogenetic analysis based on the $16 \mathrm{~S}$ rRNA gene sequences of the strains tentatively identified was conducted following the method by YANAGI and YAMASATO ${ }^{12)}$.

\section{Physicochemical analysis}

Physicochemical properties of the fish sauce mash and products, such as $\mathrm{NaCl}, \mathrm{pH}$, total nitrogen (TN), and formol nitrogen ( $F N)$, were determined in accordance with the methods authorized by the

Table 1 Materials used to prepare low-salt fish sauce with yeast

\begin{tabular}{lcccccc}
\hline \multicolumn{1}{c}{ Fish sauce } & Anchovy $(\mathrm{g})$ & Salt $(\mathrm{g})$ & Wheat koji* $(\mathrm{g})$ & Glucose $^{* *}(\mathrm{~g})$ & Yeast $(\operatorname{cells})$ & Total $(\mathrm{g})$ \\
\hline Glucose-added & 5,000 & 556 & - & 667 & $6.2 \times 10^{9}$ & 6,223 \\
Koji-added & 4,500 & 500 & 1,156 & - & $6.2 \times 10^{9}$ & 6,156 \\
\hline
\end{tabular}

* Prepared as described in Materials and Methods section.

* * Added after washed and suspended with small amount of $10 \% \mathrm{NaCl}$ solution. 
Association of Official Analytical Chemists ${ }^{13)}$. Reducing sugar (RS) and alcohol were determined by the methods authorized by the Japanese Society for Soy Sauce ${ }^{14)}$. Briefly for RS, $10 \mathrm{~m} \ell$ of diluted sample, $20 \mathrm{~m} \ell$ of Fehling's solution, and $20 \mathrm{~m} \ell$ of water were mixed in a $200 \mathrm{~m} \ell$ flask and boiled for 2 min. The mixture was then cooled, and $10 \mathrm{~m} \ell$ of $25 \%$ sulfuric acid was added. Immediately after 3 $\mathrm{g}$ of KI was added, the mixture was titrated with $0.1 \mathrm{~N} \mathrm{Na}_{2} \mathrm{~S}_{2} \mathrm{O}_{3}$. The RS content was calculated as the value corresponding to glucose. Briefly for the determination of alcohol content, $10 \mathrm{~m} \ell$ of the sample was distilled to obtain volatile compounds, including alcohols, and then distillate was added to make 100 $\mathrm{m} \ell ; 5 \mathrm{~m} \ell$ of the distillate was mixed with $5 \mathrm{~m} \ell$ of $0.1 \mathrm{~N} \mathrm{~K}_{2} \mathrm{Cr}_{2} \mathrm{O}_{7}$ and then $10 \mathrm{~m} \ell$ of concentrated $\mathrm{H}_{2} \mathrm{SO}_{4}$ was added to the mixture. After the mixture was left for $30 \mathrm{~min}$ at room temperature, KI was added, and the mixture was titrated with $0.1 \mathrm{~N} \mathrm{Na}_{2} \mathrm{~S}_{2} \mathrm{O}_{3}$. The alcohol content was calculated as that corresponding to ethanol.

\section{Preference test}

The acceptabilities of the low-salt fish sauces were evaluated in accordance with their flavor profiles. The panelists selected on the basis of interest and availability were 30 Japanese (13 men and 17 women; mean age : 22 years) who were well acquainted with sensory evaluation methods. Samples were diluted with hot water at $90^{\circ} \mathrm{C}$ to a concentration of $1 \% \mathrm{NaCl}$; odor was evaluated by sniffing, and the sauces were tasted. After sensory evaluation, the overall preferences of the low-salt fish sauces were scored as pleasant $(+2)$; not good, not bad $(+1)$; and unpleasant $(0)$; the rcasons for the scores given were recorded. Before the low-salt fish sauces were evaluated, commercial fish sauces were examined in the same way as were the traditional fish sauces.

\section{Results and Discussion}

\section{Bacteria in the spoiled low-salt fish sauce mash}

In general, when the total population of undesirable bacteria increases beyond $10^{6}$ cells/g of matter, it indicates spoilage. To investigate the nature of the bacterial flora in the spoiled fish sauce mash under low salt concentrations, we prepared a $10 \% \mathrm{NaCl}$ fish sauce from which we isolated a total of 48 strains from the mash. To another $10 \% \mathrm{NaCl}$ fish sauce, we added $5 \%$

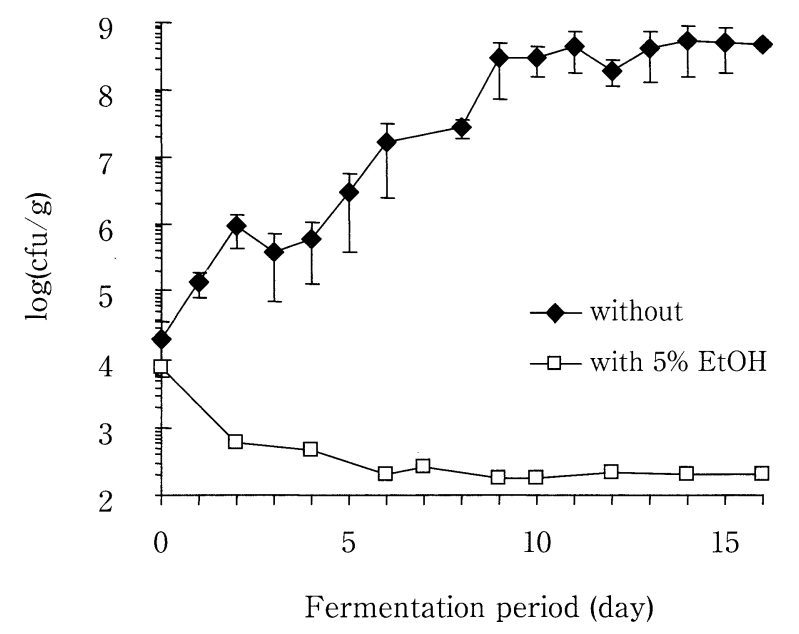

Fig. 1 Mean changes in bacteria in $10 \% \mathrm{NaCl}$ fish sauce mash with and without addition of $5 \%$ ethanol. Vertical bars indicate standard error

ethanol to see whether the alcohol would prevent bacterial growth. In the $10 \% \mathrm{NaCl}$ fish sauce mash, bacterial growth greatly increased to $10^{8} \mathrm{cfu} / \mathrm{g}$ during the first 10 days of fermentation (Fig. 1), whereas bacterial growth was completely inhibited throughout the fermentation period in the 10\% $\mathrm{NaCl}$ fish sauce mash to which $5 \%$ ethanol had been added. Thirty-five bacterial strains isolated from the mashes were identified (on the basis of Bergey's manual and phylogenetic analysis, i.e, $16 \mathrm{~S}$ rRNA gene sequencing) as Staphylococcus species (round-shaped, gram-positive, non-spore-forming, nonmotile, catalase-positive, and facultatively anaerobic). The bacteria identified as Staphylococcus species were isolated from the mashes every 2 days during the fermentation period, whereas those identified as gram-negative and facultatively anaerobic were isolated from the mashes only on day 2 and day 4 of fermentation. On the basis of these results, it was considered that the gramnegative facultative anaerobic bacteria grew for a short period at the beginning of fermentation, and subsequently Staphylococci growth was dominant.

YАмАмото et $a l^{15}$. investigated the inhibitory activity of ethanol on food spoilage bacteria under an unsalted condition. They reported that the minimum growth inhibitory concentration of ethanol against gram-positive bacteria was $8 \sim 11 \%$, and that against gram-negative facultative anaerobic bacteria was less than $9 \%$. It was found that the addition of $5 \%$ ethanol to the $10 \% \mathrm{NaCl}$ fish sauce mash was effective in inhibiting bacterial growth during fermentation. 


\section{Selection of yeast for the preparation of low-} salt fish sauce

We isolated 22 strains of yeast from the soy sauce mash to produce ethanol during fermentation to prevent the mash from spoiling. The isolated strains were identified as $Z$. rouxii on the basis of their morphological and physiological properties (data not shown). The yeast underwent a primary screening to determine which strain would grow the fastest in YM broth containing $10 \% \mathrm{NaCl}$ (Fig.2). The five strains selected after the primary screening were secondarily screened to determine which strain would produce the greatest amount of ethanol from glucose during growth in YM broth containing $10 \% \mathrm{NaCl}$ and $10 \%$ glucose. As a result, the A-9 strain was selected for making the low-salt fish sauce.

3. Effect of initial level of yeast on growth of bacteria in low-salt fish sauce mash

To study the effect of the addition of yeast on bacterial growth in $10 \% \mathrm{NaCl}$ fish sauce mash, $Z$. rouxii A-9 was added to three batches of the $10 \%$ $\mathrm{NaCl}$ fish sauce mash at a population of $10^{4} \mathrm{cfu} / \mathrm{g}$ (batch A), $10^{5} \mathrm{cfu} / \mathrm{g}$ (batch B), or $10^{6} \mathrm{cfu} / \mathrm{g}$ (batch C) and incubated for 5 days. Glucose (10\%) was added to the mashes as a carbon source for fermentation by yeast. The results are shown in Fig. 3. Bacterial growth was less than $10^{4} \mathrm{cfu} / \mathrm{g}$ in batch $\mathrm{C}$, whereas bacterial growths were $10^{8} \mathrm{cfu} / \mathrm{g}$ and $10^{7} \mathrm{cfu} / \mathrm{g}$ in batches $\mathrm{A}$ and $\mathrm{B}$, respectively within 3 days. Yeast did not grow to $10^{7} \mathrm{cfu} / \mathrm{g}$ in batches $\mathrm{A}$ and $\mathrm{B}$ but grew well only when added
A

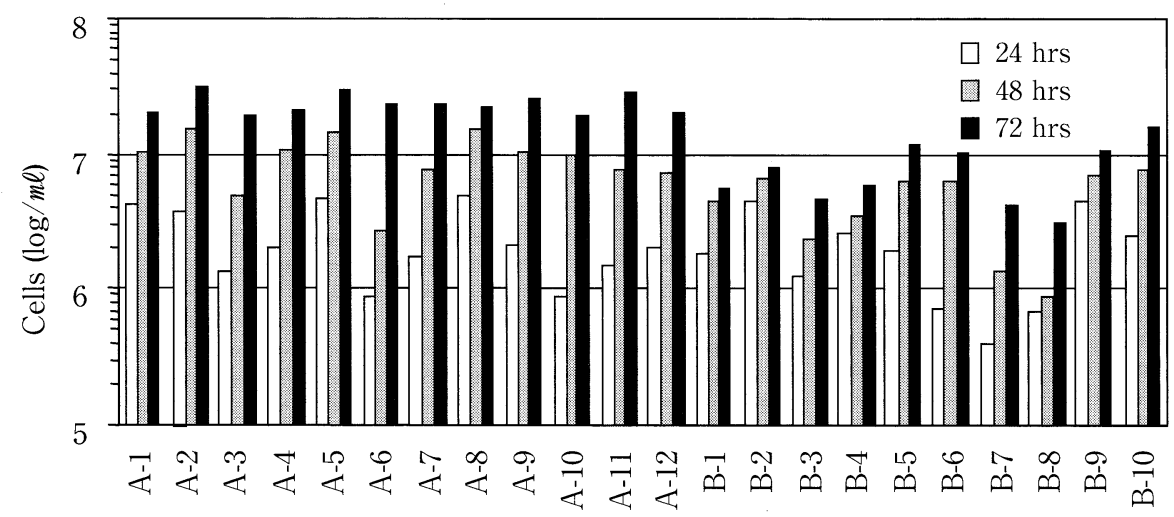

Strain Number

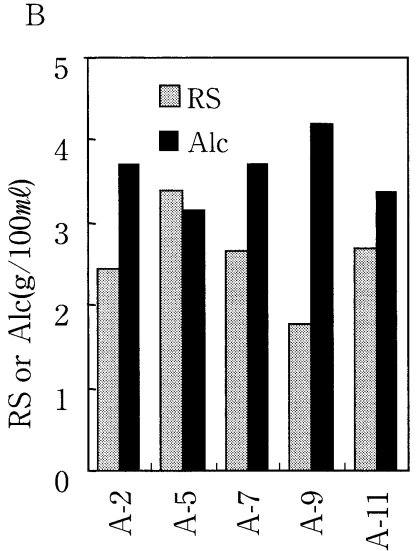

Strain Number

Fig. 2 Screening results of strains isolated from soy sauce mash

A : Primary screening to determine which strain would grow fastest in GYP medium containing $10 \% \mathrm{NaCl}$.

B : Secondary screening to determine which strain would produce greatest amount of ethanol (Alc) from $10 \%$ glucose (RS) during growth in GYP broth containing $10 \% \mathrm{NaCl}$ and $10 \%$ glucose.
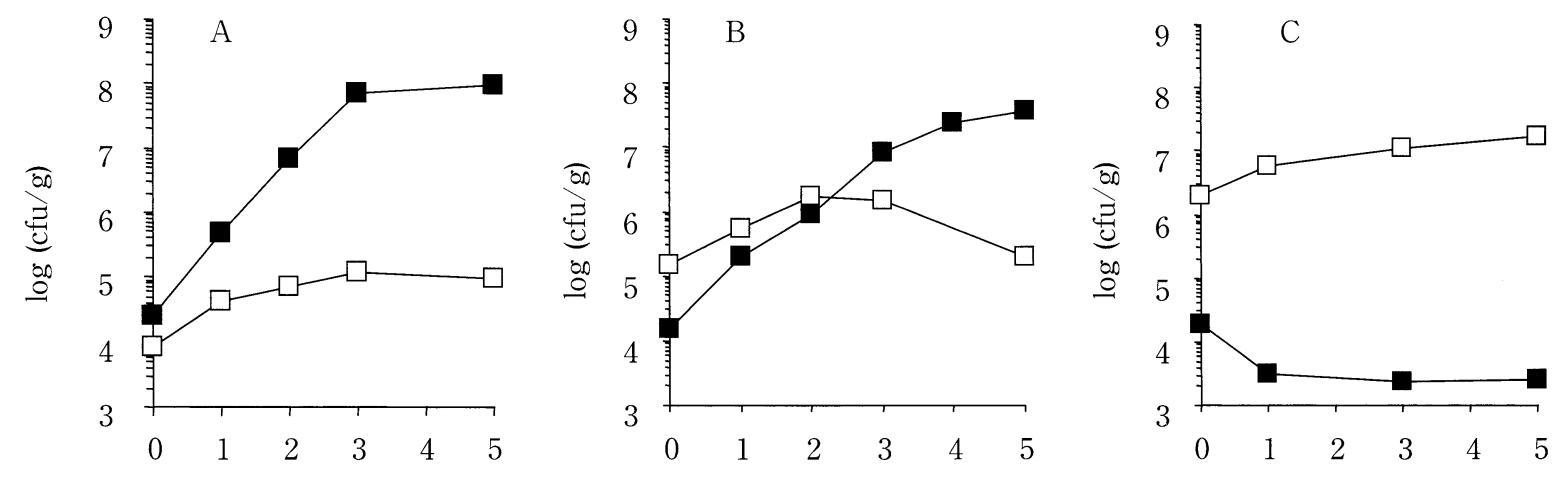

Fermentation period (day)

Fig. 3 Effect of initial level of yeast on growth of bacteria 
at $10^{6}$ cells / $\mathrm{g}$ of initial level in batch $\mathrm{C}$. It was considered that $10^{6} \mathrm{cfu} / \mathrm{g}$ of yeast in batch $\mathrm{C}$ started alcohol fermentation before bacteria grew and thereby yeast could grow inhibiting bacterial growth, although yeast could not grow in batches $\mathrm{A}$ and $\mathrm{B}$ because of growth competition with bacteria. On the basis of these results, it was concluded that the addition of at least $10^{6}$ cells / g Z r rouxii A-9 was required to inhibit bacterial growth in the low-salt fish sauce mash.

\section{Preparation of low-salt fish sauce using $10^{6}$ cells/ $\mathrm{g}$ of starter yeast}

Two types of $10 \% \mathrm{NaCl}$ fish sauce were prepared by adding $10^{6}$ cells/g of yeast in order to produce ethanol and inhibit the growth of bacteria, which contribute to spoilage of the mash during fermentation. The growth of microbes and changes in physicochemical components in the mash of glucose-added low-salt fish sauce were monitored, as shown in Figs. $4 \mathrm{~A}$ and $4 \mathrm{~B}$, respectively. In the mash, the viable cell count of the yeast increased from $10^{6} \mathrm{cfu} / \mathrm{g}$ to $10^{7} \mathrm{cfu} / \mathrm{g}$ during the first 10 days and then gradually decreased to $10^{6} \mathrm{cfu} / \mathrm{g}$ by day 20 and to less than $10^{5} \mathrm{cfu} / \mathrm{g}$ by day 35 (data not shown). The viable cell count of bacteria in the

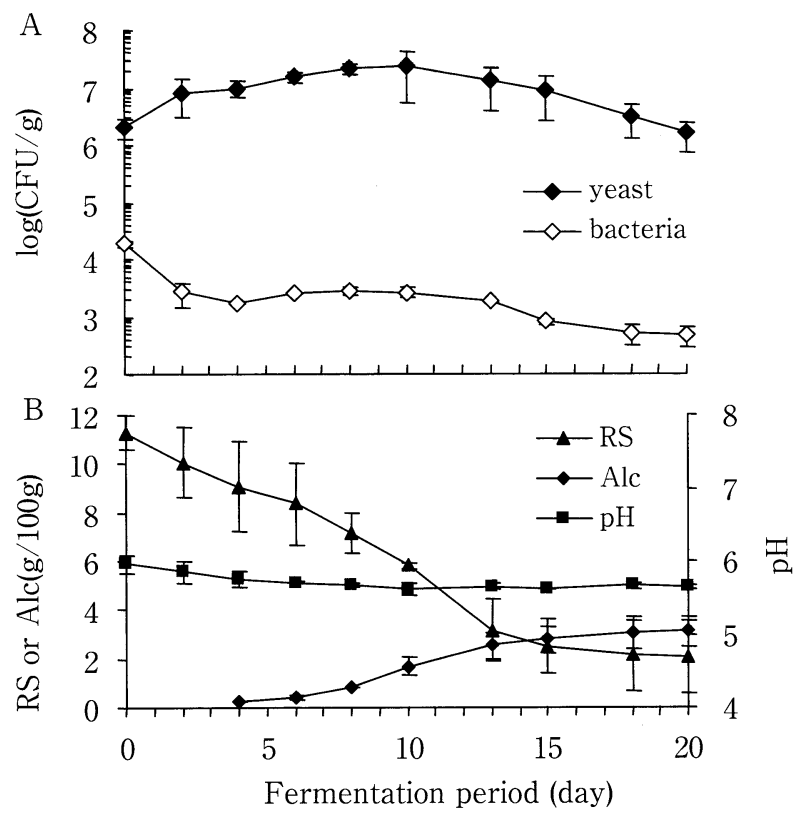

Fig. 4 Fermentation of low-salt fish sauce mash to which glucose and yeast are added

A : Growth of yeast and bacteria. B : Changes in reducing sugar (RS), ethanol (Alc), and pH. Low-salt fish sauce mash was prepared by mixing $5,000 \mathrm{~g}$ of anchovy with $556 \mathrm{~g}$ of salt, and 667 $\mathrm{g}$ of glucose, to which $Z$. rouxii A-9 $\left(10^{6}\right.$ cells/ $\mathrm{g}$ of the mixture of materials) is added. The experiments were duplicated. Vertical bars indicate standard errors. mash remained less than $10^{4} \mathrm{cfu} / \mathrm{g}$ throughout the fermentation. The alcohol content of the fish sauce mashes increased gradually with yeast growth and reached a concentration of $3 \mathrm{~g} / 100 \mathrm{~g}$ after 15 days. In contrast, the sugar content decreased from 11 to $2.5 \mathrm{~g} / 100 \mathrm{~g}$ during the first 15 days and to $1.4 \mathrm{~g} /$ $100 \mathrm{~g}$ after 35 days (data not shown). In yeast fermentation $11 \mathrm{~g} / 100 \mathrm{~g}$ of glucose should be theoretically converted to $5 \mathrm{~g} / 100 \mathrm{~g}$ of ethanol which was effective in inhibiting bacterial growth as shown in Fig. 1. However, a part of glucose remained not consumed by yeast and a small part of alcohol was likely lost by evaporation during fermentation. From these results, it was suggested that $3 \mathrm{~g} / 100 \mathrm{~g}$ of ethanol was enough to inhibit bacterial growth in the low salt fish sauce mash including yeast and glucose. The $\mathrm{pH}$ remained at approximately 5.7 throughout the fermentation period. The finding that bacterial growth did not exceed $10^{4} \mathrm{cfu} / \mathrm{g}$ and that the $\mathrm{pH}$ remained constant at approximately 5.5 throughout the fermentation period indicated that no spoilage occurred in the mash. The addition of high levels of yeast $\left(10^{6}\right.$ cells $/ \mathrm{g}$ ) to the mash probably had 2 effects on bacteria: it decreased the number of bacteria at the beginning of the fermentation period, and then the alcohol produced gradually by the yeast beginning on day 8 inhibited the growth of bacteria. Changes in microbes and chemical components in the low-salt fish sauce mashes with koji were not considerably different from those in the mashes with glucose; slightly greater numbers of bacteria were detected in the koji mash at the early stage of fermentation (data not shown).

\section{Chemical components of low-salt fish sauce products}

The low-salt fish sauce mashes were pressed to terminate the fermentation on day 35 . The chemical compositions of the low-salt fish sauce products and commercial fish sauce are indicated in Table 2. The chemical compositions of the two low-salt fish sauces ( glucose-and koji-added) were similar, but the nitrogen content was higher and the sugar content was lower in the koji-added sauce than in the glucose-added sauce. This difference was attributed to the wheat gluten content of koji. The salt content of both low-salt fish sauces was half that of the commercial fish sauce, although the nitrogen content of the low-salt fish sauces was slightly higher than that of the commercial fish sauce. The 
Table 2 Chemical components of fish sauce products

\begin{tabular}{|c|c|c|c|c|c|c|}
\hline Fish sauce & $\begin{array}{c}\mathrm{NaCl} \\
(\mathrm{g} / 100 \mathrm{~m} \ell)\end{array}$ & $\begin{array}{c}\text { TN } \\
(\mathrm{g} / 100 \mathrm{~m} \ell)\end{array}$ & $\begin{array}{c}\mathrm{FN} \\
(\mathrm{g} / 100 \mathrm{~m} \ell)\end{array}$ & $\begin{array}{c}\mathrm{RS} \\
(\mathrm{g} / 100 \mathrm{~m} \ell)\end{array}$ & $\begin{array}{c}\text { Alc } \\
(\mathrm{g} / 100 \mathrm{~m} \ell)\end{array}$ & $\mathrm{pH}$ \\
\hline $\begin{array}{l}\text { Commercial } \\
\text { fish sauce* }\end{array}$ & $25.68 \pm 1.64$ & $2.46 \pm 0.51$ & $1.28 \pm 0.22$ & $0.66 \pm 0.27$ & ND & $5.49 \pm 0.26$ \\
\hline $\begin{array}{l}\text { Low-salt } \\
\text { fish sauce } \\
\text { (glucose-added) }\end{array}$ & $12.70 \pm 0.25$ & $2.51 \pm 0.05$ & $1.34 \pm 0.03$ & $2.50 \pm 1.19$ & $2.02 \pm 0.44$ & $5.76 \pm 0.14$ \\
\hline $\begin{array}{l}\text { Low-salt } \\
\text { fish sauce** } \\
\text { (koji-added) }\end{array}$ & $12.17 \pm 0.46$ & $2.68 \pm 0.01$ & $1.53 \pm 0.01$ & $1.58 \pm 0.78$ & $2.13 \pm 0.19$ & $5.64 \pm 0.09$ \\
\hline $\begin{array}{l}\text { * Data were obta } \\
\text { salt. } \\
\text { * * These low-salt } \\
\text { TN : total nitro } \\
\text { Values are repr }\end{array}$ & $\begin{array}{l}\text { from } 4 \text { comm } \\
\text { sauces were } m \\
\text { FN: formol } n \\
\text { ted as mean } \pm\end{array}$ & $\begin{array}{l}\text { fish sauces, } \\
\text { by using yea } \\
\text { en, RS: redu }\end{array}$ & $\begin{array}{l}\text { se ingredien } \\
\text { this study. } \\
\text { sugar, Alc: }\end{array}$ & $\begin{array}{l}\text { ere indicated } \\
\text { holalcohol. }\end{array}$ & heir labels as & anchovy \\
\hline
\end{tabular}

low-salt fish sauce contained more sugar and alcohol than commercial sauces. However, the higher sugar content of the low-salt fish sauce is considered to be advantageous because it improves the overall taste by making the sauce milder and thicker. In contrast, the disadvantage of the higher sugar content is that it can lead more easily to a Maillard reaction, which can result in browning of the product during storage. The glucose content at the beginning of fermentation should be optimized to reduce the residual sugar content. On the other hand, alcohol produced from sugar by yeast was considered to contribute to sensory property as a component of favorable flavors. An abundance of pyroglutamic acid $(738.5 \mathrm{mg} / 100 \mathrm{~m} \ell)$ was detected in the koji-added low-salt fish sauce (data not shown). Because glutamine is a major component of wheat gluten, the material used to make koji, it was apparent that considerable amounts of pyroglutamic acid produced from glutamine released from the koji material during fermentation. However, further study showed that the addition of glutaminase C 300 S (Daiwa Kasei K. K., Tokyo, Japan) to the mash at a concentration of $50 \mathrm{mg} / 100 \mathrm{~g}$ was effective at increasing the content of glutamic acid. The kojiadded low-salt fish sauce product that we prepared had a glutamic acid content of $2.1 \mathrm{~g} / 100 \mathrm{~m} \ell$ (data not shown), whereas its amount in a traditional fish sauce is usually $1 \mathrm{~g} / 100 \mathrm{~m}^{16), 177}$.

In a taste-preference test, both low-salt fish sauces prepared using yeast were preferred to commercial products, because of their stronger umami taste and more favorable flavor. Because of the low salt content, the umami taste was more distinct in both of the low-salt fish sauces than in the traditional products. The low-salt fish sauces did not have a fishy odor but rather had a fermented flavor similar to that of soy sauce. It is known that HEMF [4hydroxy-2 (5) -ethyl-5 (2) -methyl-3 (2H) -furanone ], which has been approved as responsible for the distinctive flavor of soy sauce, is produced by yeast during the fermentation of soy sauce and miso $^{18)}$. For this reason, the low-salt fish sauces prepared using high levels of yeast are considered acceptable by the Japanese who use soy sauce. We anticipate that this low-salt fish sauce will become widely used as a food seasoning because it adds a favorable umami taste to various dishes without excessive saltiness or a distinctive odor.

Acknowledgments We are grateful to Dr. K. Yamasato (Tokyo University of Agriculture) for valuable advice regarding the isolation and identification of bacteria, and Dr. Hirokazu Tani (Daiwa Kasei K. K.) for kindly providing glutaminase C $300 \mathrm{~S}$. We also thank Ms. H. Katakura, Mr. H. Shinozaki, and Mr. S. Okutsu for their technical assistance.

\section{References}

1) Dougan, J. and Howard, G.E.: Some flavouring constituents of fermented fish sauces, J. Sci. Food Agric., 26, 887 894 (1975)

2 ) Mciver, R. C., Brooks, R. I. and Reineccius, G. A.: Flavor of fermented fish sauce, J. Agric. Food Chem., 30, 1017 1020 (1982) 
3 ) Peralta, R. R., Shimoda, M. and Osajima, Y. : Further identification of volatile compounds in fish sauce, J. Agric. Food Chem., 44, 3606 3610 (1996)

4 ) Fukami, K., Ishiyama, S., Yaguramaki, H., Masuzawa, T., Nabeta, Y., Endo, K. and Shimoda, M.: Identification of distinctive volatile compounds in fish sauce, J. Agric. Food Chem., 50, 5412 5416 (2002)

5 ) Saisithi, P., Kasemsarn, B-O., Liston, J. and Dollar, A.M. : Microbiology and chemistry of fermented fish, J. Food Sci., 31, 105 110 (1966)

6 ) Sanceda, N., Suzuki, E. and Kurata, T. : Development of normal and branched chain volatile fatty acids during the fermentation process in the manufacture of fish sauce, $J$. Sci. Food Agric., 81, 1013 1018 (2001)

7 ) Matsumoto, I. and Imai, S.: Use of Sacch. rouxii in low salted soy sauce brewing, J. Brew. Soc. Japan, 78, 398〜401 (1983)

8 ) Fujil, T., Bambang, B. and Tozawa, H.: Chemical composition and microflora of fish sauce "patis", Bull. Jpn. Soc. Sci. Fish, 46, 1235 1240 (1980)

9 ) Sneath, P.H.A., Mair, N.S., Sharpe, M.E. and Holt, J. G. : Bergey's Manual of Systematic Bacteriology. Vol.2. (Williams and Wilkins, Baltimore, MD) (1986)

10) FujII, T. and SAKAI, H. : Chemical and microbiological analyses of putrid fish sauce "Shottsuru", Bull. Jpn. Soc. Sci. Fish, 50, 1067〜1070 (1984)

11) Cowan, S. T. and Steel, K. J.: Manual for the Identification of Medical Bacteria ( 2 nd ed) (Cambridge University Press, London) (1974)

12) Yanagi, M. and Yamasato, K. : Phylogenetic analysis of the family Rhizobiaceae and related bacteria by sequencing of $16 \mathrm{~S}$ rRNA gene using PCR and DNA sequencer, FEMS Microbiol. Lett., 107, 115 120 (1993)

13) AOAC: Official Methods of Analysis of Association of Official Analytical Chemists International. 16 th ed., Virginia (1996)

14) Japanese Institute for Soy Sauce: Standard Method for Soy Sauce Analysis. Japanese Institute for Soy Sauce, Tokyo (1985)
$15)$ Yamamoto, Y., Higashi, K. and Yoshil, H. : Inhibitory activity of ethanol on food spoilage bacteria. Nippon, Shokuhin Kogyo Gakkaishi, 31, 531 〜 535 (1984)

16) Mizutani, T., Kimizuka, A., Ruddle, K. and IsHige, N.: Chemical components of fermented fish products, J. Food Comp. Anal., 5, 152 159 (1992)

17) Park, J. N., Fukumoto, Y., Fujita, E., Tanaka, T., Washio, T., Otsuka, S., Shimizu, T., Watanabe, K. and $\mathrm{ABE}, \mathrm{H}$.: Chemical composition of fish sauces produced in Southeast and East Asian countries, $J$. Food Comp. Anal., 14, 113 125 (2001)

18) Hayashida, Y., Nishimura, K. and Slaughter, J. C.: The influence of mash pre-aging on the development of the flavour-active compound, 4 hydroxy-2 (or 5 ) -ethyl-5 ( or 2) -methyl-3 (2 H) furanone (HEMF), during soy sauce fermentation, Int. J. Food Sci. Technol., 32, 11 14 (1997)

\section{酵母を利用した低食塩魚罗油の開発}

$$
\begin{gathered}
\text { 前橋健二**山本 泰* } \\
\text { * 東京農業大学応用生物科学部醇造科学科 } \\
\text { ( ₹ 156-8502 東京都世田谷区桜丘 } 1-1-1 \text { ) }
\end{gathered}
$$

奨油酵母Zygosaccharomyces rouxiiを利用した低食塩魚 奨油の製造について検討を行った。10\%食塩魚奨油諸味 中では腐敗細菌は $10^{8} \mathrm{cfu} / \mathrm{g}$ 以上に増殖したが，5\%エ夕 ノールを添加することによりそれらの生育は発酵期間中 $10^{2} \mathrm{cfu} / \mathrm{g}$ にまで抑制されていた。㽜油酵母による生成エ 夕ノールで低食塩魚盉油諸味の腐敗を防止することを目 的とし, 奨油諸味から $10 \%$ 食塩含有培地中で良好な生育 と高い発酵力を示すZ. rouxii A-9株を分離した。A-9株 $10^{6} \mathrm{cells} / \mathrm{g}$ 用い，発酵基質としてグルコースまたは小 麦麹を添加した低食塩魚奨油の製造を行った。添加した 酵母は低食塩魚酱油諸味中で増殖し，糖を消費しながら アルコールを生成し細菌の増殖を抑制した。発酵は60日 間で終了し製品とした。グルコース添加低食塩魚滰油と 贅添加低食塩魚酱油には成分の差はほとんどみられず, どちらも市販の伝統的魚奨油と比較して食塩濃度は半分 であり，官能的に市販伝統的魚奨油のような特有の臭気 はなく好ましい発酵香が得られた。

(平成19年 5 月 9 日受付，平成19年10月 2 日受理) 